\title{
The Fairy Valley
}

by John E. Nixon, Wauchope

The elves and the fairies, so some people say,

Left us forever one midsummer day;

But I know a valley-a cup in the hills-

A green place of wonder, where strange music thrills.

A vale where in summer the shadows are cool.

Where I love to linger when I come from school.

For have I not seen there more wonderful things

Than ever were dreamed of in castles of kings.

The elves and the fairies are gone, so I'm told.

But I know a deep glade they haunt as of old;

A circle of magic, where bird, beast and bee,

Are one with enchantment that few eyes can see.

Where gold shafts of sunlight glance down through the leaves.

I stand wrapt in silence, and fantasy weaves

A spell all around me, and opens my eyes

To marvels well hidden from mortals more wise.

A woodpecker tapping ... 'tis a dwarf in his mine! Dew caught in a harebell ... 'tis Oberon's wine!

A wren shrilly scolding from some mossy bank,

Is Puck bent on mischief in some crazy prank!

And high up above me, unfearful of man,

A thrasher is singing . . . 'tis the wild pipes of Pan!

They say that the fairies no longer are found,

But I know my valley is still faerie ground! 